\title{
SCALING UP THE INNOVATION PROCESS IN THE ENERGY SECTOR ON THE BASIS OF TECHNOLOGY ENTREPRENEURSHIP
}

\author{
LAZAR D. GITELMAN ${ }^{1}$, MIKHAIL V. KOZHEVNIKOV ${ }^{1}$, EVGENIY M. STARIKOV ${ }^{1}$ \& ELENA C. RADA ${ }^{2}$ \\ ${ }^{1}$ Department of Energy and Industrial Management Systems, Ural Federal University, Russia \\ ${ }^{2}$ Department of Theoretical and Applied Sciences, University of Insubria, Italy
}

\begin{abstract}
The liberalization of the energy sector, the spreading adoption of digital information and telecommunication technologies, decentralization, and expansion of RES-based distributed generation provide broader development opportunities for technology entrepreneurship in the industry. Nevertheless, the energy sector remains one of the "least entrepreneurial" industries of the global economy - both by number of corporate innovations and by number of independent startups. Having summarized a corpus of theoretical research and the results of a survey of energy experts, the authors were able to describe fields of applications and key barriers to the development of technology entrepreneurship in the industry and at a corporate level. On the basis of an analysis of the experience of US and British energy companies, the authors propose typical models of technology entrepreneurship and schemes of resource interaction among energy companies, consumers of new products and services, universities, developers and investors in the course of implementation of breakthrough projects. The results of the study and the authors' recommendations can be used by energy companies creating corporate mechanisms of technology entrepreneurship, as well as by government agencies and universities for the development of the innovation infrastructure of the energy sector.
\end{abstract}

Keywords: technology entrepreneurship, startup, smart energy, digitalization, technology modernization, innovation infrastructure.

\section{INTRODUCTION}

The authors define technology entrepreneurship as a high-risk activity of implementing projects that are aimed at creating new technologies on the basis of systems of continuous search for emerging opportunities, transformation of the newest scientific and technical developments into original business ideas and accumulation of dispersed resources that are required for bringing innovative products and services to the market. Created technologies may be represented as supporting innovations in various fields (management, energy production, business models), and disruptive, fundamentally changing the entire market landscape [1].

Interest in this phenomenon peaks at the moments of radical technological shifts. As shown in [2], [3], technology entrepreneurship plays a support role at the growth stages of an innovation's life cycle that is represented by Gartner's hype cycle.

In the Technology Trigger phase, the task of technology entrepreneurship is to boost research and the launch of startups, to forge partnerships and strategic alliances. In the phases of secondary growth and robust productivity (Slope of Enlightenment and Plateau of Productivity), technology entrepreneurship has an adjustment function of helping organizations to chisel technological solutions and complete the market adaptation to new products.

Apart from that, big companies and universities, who are the main "consumers" of technology entrepreneurship, view it as a source of organizational flexibility and a fuel for corporate innovation spirit as technology entrepreneurs often operate as creative local teams that focus on various engineering and marketing aspects of a technological solution [4], [5]. 
In the energy sector that is currently going through radical transformations resulting from broad smartization, energy market reconfiguration, the expansion of RES-based distributed generation and smart grids, electric transport and energy storage and accumulation solutions, technology entrepreneurship has been developing at a slower pace as compared to other industries. It is estimated that expenditures for R-and-D in the energy sector have been stagnating since 2012. In 2015, investment in technological innovations globally amounted to $67 \mathrm{bn}$ dollars, which is only $4 \%$ of the global energy investment [6]. Moreover, in 20152016, investment to modernize the grid and generating facilities showed a slight downward trend - for the first time in 15 years. By contrast, in the IT industry, nearly $40 \%$ of total investment was directed towards the development of innovative solutions [7].

Nevertheless, a number of successful examples show that technology entrepreneurship could be an effective and indispensable mechanism for boosting innovation - both at the level of individual energy companies and at an industry level. In this study, we will identify typical barriers to technology entrepreneurship development and formulate models and schemes of resource interaction in the process of implementing breakthrough projects among energy companies, consumers of new products and service, universities, developers, and investors. In conclusion, we will give recommendations for heads of energy companies and government bodies as regards the creation of effective infrastructure that supports the development of this area.

\section{CHARACTERISTICS OF TECHNOLOGY ENTREPRENEURSHIP}

Technology entrepreneurship has been on scholars' radar since the 1980s. The scientific community was, however, more interested in the economic rather than process-related aspects: for example, the issue of value migration, the ability of technology to be sold as a standalone product, the structure of the market for technology [8]-[11]. In the early 2000s, Shane and Venkataraman attempted to provide a more universal understanding of technology entrepreneurship by defining it as an activity aimed at "assembling organizational resources and technical systems, and the strategies used by entrepreneurial firms to pursue opportunities" [12]. Later, Bailetti summarized the works of many of his earlier counterparts and defined technology entrepreneurship as an investment in a project that assembles and deploys specialized individuals and heterogeneous assets advancing scientific and technological knowledge to create and capture value for the firm [13].

At the forefront of technology entrepreneurship there is a search for new, breakthrough and research-intensive technologies (a device, a computer program, or a unique service) that guarantee a firm or a business eco-system a long-lasting competitive edge and that have a value to the scientific community thanks to their substantial hidden potential as a research subject.

As the end product requires a large volume of new scientific knowledge that can hardly be generated by a single structure, be it a high-tech company, a startup or a university, those involved in the process of technology entrepreneurship have to engage in close cooperation.

Such cooperative groups might include:

- $\quad$ scientists/ research teams/universities;

- independent entrepreneurs/ business-structures/investors;

- enthusiasts/ pro-active employees.

The makeup of participants, the focus of research and development projects, the degree of novelty and continuity in technologies being created serve as the classification characteristics for technology entrepreneurship. In our view, the characteristics could be used for identifying the typical forms of technology entrepreneurship that differ in terms of stakeholders involved, nature of their interaction and market goals (Table 1). 
Various forms of technology entrepreneurship could appear in various business models. Gabriel and Kirkwood [14] used a survey of over 100 respondents in 28 countries to derive four business models in technology entrepreneurship that are typical of the energy sector and complex industries. The models are termed "Consultants", "Distributors", "Integrators", and "Technology Owners" (Fig. 1).

The main differences between the above business models lie in the comprehensiveness of the product offering and their focus on one or several stages of the lifecycle of the innovative process. "Consultants" as the most basic type of technology business tend to provide service rather than manufacture tangible products. They offer the most versatile range of auxiliary services within the lifecycle of an innovation: market analysis and forecasting, product and systems design, expert analysis of research-intensive solutions, consulting. "Distributors" act as technology intermediaries between the developers and buyers of new systems.

Table 1: Forms of technology entrepreneurship.

\begin{tabular}{|c|c|c|}
\hline Characteristics & Short description & Details \\
\hline \multirow{4}{*}{$\begin{array}{l}\text { Participant } \\
\text { makeup }\end{array}$} & Firm & $\begin{array}{l}\text { The firm only uses its own resources to implement } \\
\text { technology entrepreneurship projects }\end{array}$ \\
\hline & $\begin{array}{l}\text { Firm and university } \\
\text { (also individual } \\
\text { scientists or research } \\
\text { teams) }\end{array}$ & $\begin{array}{l}\text { The firm cooperates with the university (as a } \\
\text { whole or individual scientists/ research teams) and } \\
\text { participates in experience exchange events }\end{array}$ \\
\hline & $\begin{array}{l}\text { Startup (in cooperation } \\
\text { with investors) }\end{array}$ & $\begin{array}{l}\text { A group of enthusiasts sets up a small technology } \\
\text { firm that uses investors' funds for growth and } \\
\text { product development }\end{array}$ \\
\hline & $\begin{array}{l}\text { University (in } \\
\text { cooperation with } \\
\text { consultants and } \\
\text { investors) }\end{array}$ & $\begin{array}{l}\text { The university's intellectual property is } \\
\text { commercialized with the assistance of investors } \\
\text { and business consultants }\end{array}$ \\
\hline \multirow{4}{*}{$\begin{array}{l}\text { Focus of } \\
\text { research }\end{array}$} & $\begin{array}{l}\text { Corporate research } \\
\text { undertaken in-house }\end{array}$ & $\begin{array}{c}\text { Innovations are developed and utilized within the } \\
\text { company }\end{array}$ \\
\hline & \begin{tabular}{|c|} 
Externally \\
commissioned research
\end{tabular} & $\begin{array}{c}\text { The company makes an } R \& D \text { request that is } \\
\text { delivered by market participants }\end{array}$ \\
\hline & University spinoff & $\begin{array}{l}\text { The university conducts a series of studies the } \\
\text { results of which are patented or form a foundation } \\
\text { for a small innovative business in which the } \\
\text { university is the principal shareholder }\end{array}$ \\
\hline & “Garage" R\&D & $\begin{array}{l}\text { Individual enthusiasts or groups of enthusiasts } \\
\text { who work on technologies of interest (e.g. first } \\
\text { PCs assembled in California) }\end{array}$ \\
\hline \multirow{3}{*}{$\begin{array}{l}\text { Relation to } \\
\text { existing } \\
\text { technology }\end{array}$} & New technologies & $\begin{array}{l}\text { Technological solutions that are completely new } \\
\text { to the market (breakthrough innovations) }\end{array}$ \\
\hline & $\begin{array}{l}\text { Existing technology } \\
\text { modernized }\end{array}$ & $\begin{array}{c}\text { New technology functionality discovered, or } \\
\text { technology properties transformed to improve } \\
\text { work of systems }\end{array}$ \\
\hline & $\begin{array}{c}\text { Mix of existing and new } \\
\text { technologies }\end{array}$ & $\begin{array}{l}\text { When used together, they acquire new properties and } \\
\text { become a new product (e.g. pilotless automobiles) }\end{array}$ \\
\hline
\end{tabular}




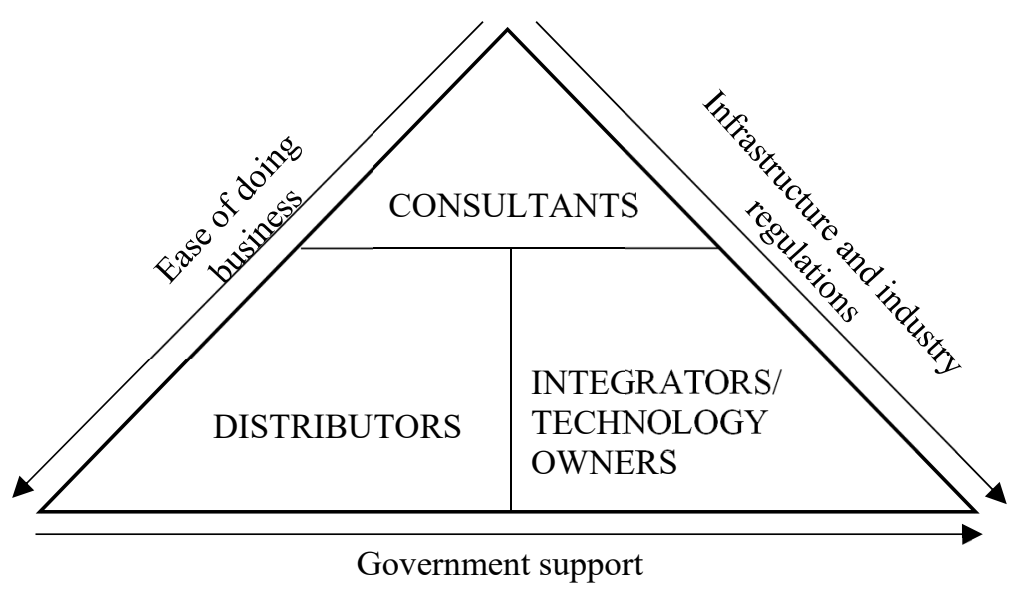

Figure 1: Triangular matrix of business models for technology entrepreneurship [14].

They specialize in the assembly of a turn-key system from different components to meet the customer's requirements. "Integrators" independently design, construct and produce complex systems while providing ancillary logistics, information and technical services. Finally, "technology owners" focus on inventing fundamentally new technological solutions and principles that can subsequently serve as the foundation for a unique production system.

The presented forms of technology entrepreneurship exist in the energy sector. There are, however, specific barriers and corporate inertia of energy company that could hamper the process of innovation. We shall take a closer look at these aspects further in the text.

\section{ANALYSIS OF GLOBAL EXPERIENCE OF TECHNOLOGY ENTREPRENEURSHIP IN THE ENERGY SECTOR}

Globally, technology entrepreneurship in the energy sector has been predominantly developing in two directions: adaptation of renewable energy sources to satisfy the requirements of mass consumption (e.g. creation of various services that enable consumers to integrate into the energy market) and creation of energy efficient and environmentally friendly technological solutions for energy systems. Technology entrepreneurship could, however, find a broader application. The authors have studied over 30 cases of technology entrepreneurship of various scales and composition (Table 2) that demonstrate the wide applicability of this tool.

Table 2 presents some of the most interesting cases of technology entrepreneurship that indicate the diversity of participants, their interdependence and the synergistic effect that arises from their cooperation and resource exchange. A separate category of cases is made up of companies that not only embrace innovative technologies, but also adopt new business models.

For example, in 2016 Siemens and LO3 Energy teamed up to build a local smart grid in Brooklyn. LO3's system is intended to let "prosumers" buy and sell energy generated from rooftop solar panels to their neighbors. LO3 users install a high-resolution meter, which tracks energy usage at specific times of day, or an app that lets them set buy and sell requests for specific kinds of electricity, such as solar or wind. LO3 gets revenue from the resulting transactions, and also wants to penetrate the bigger utility market, potentially by connecting microgrids to major utility operations. LO3 also considers using blockchain and the smart 
Table 2: Technology entrepreneurship cases in energy sector [15]-[25].

\begin{tabular}{|c|c|c|}
\hline $\begin{array}{l}\begin{array}{l}\text { Name of energy company/ } \\
\text { organization/project }\end{array} \\
\end{array}$ & Technology being introduced & Stakeholders \\
\hline $\begin{array}{l}\text { Hangzhou Zhongheng } \\
\text { Electric (China) }\end{array}$ & $\begin{array}{l}\text { Sensors concealed within workers' uniforms can } \\
\text { analyze their emotions and help increase their } \\
\text { productivity through timely job rotations }\end{array}$ & $\begin{array}{l}\text { Energy } \\
\text { company }\end{array}$ \\
\hline $\begin{array}{l}\text { Smart Grid Project in } \\
\text { Belgorod (Russia) }\end{array}$ & $\begin{array}{l}\text { "Smart" energy consumption measurement based } \\
\text { on automated system of commercial electricity } \\
\text { measurement using Neuron smart meters }\end{array}$ & $\begin{array}{l}\text { Energy } \\
\text { company and } \\
\text { state }\end{array}$ \\
\hline $\begin{array}{l}\text { Machine learning for } \\
\text { business process } \\
\text { management at General } \\
\text { Electric (USA) }\end{array}$ & $\begin{array}{l}\text { Corporate university that specializes in training } \\
\text { the company staff in machine learning } \\
\text { technology and building learning digital twins } \\
\text { that help predict equipment failures }\end{array}$ & $\begin{array}{l}\text { Energy } \\
\text { company and } \\
\text { university }\end{array}$ \\
\hline $\begin{array}{l}\text { Carnegie Mellon University } \\
\text { (USA) }\end{array}$ & $\begin{array}{l}\text { Energy consumption management system for } \\
\text { companies that incorporates a smart control board } \\
\text { for monitoring energy costs and reducing them at } \\
\text { peak loads }\end{array}$ & University \\
\hline Aquion Energy (USA) & $\begin{array}{l}\text { Aqueous Hybrid Ion Battery that uses a water- } \\
\text { based sodium sulfate electrolyte for energy } \\
\text { storage }\end{array}$ & $\begin{array}{l}\text { University and } \\
\text { startup }\end{array}$ \\
\hline Shell (USA) & $\begin{array}{l}\text { The oil company has invested in a startup that } \\
\text { sells solar energy for a flat monthly rate }\end{array}$ & $\begin{array}{l}\text { Energy } \\
\text { company and } \\
\text { startup }\end{array}$ \\
\hline Moya Power (UK) & $\begin{array}{l}\text { Big plastic sheets are installed along railways and } \\
\text { in tunnels. The sheets generate electricity by } \\
\text { capturing air streams. }\end{array}$ & Startup \\
\hline $\begin{array}{l}\text { Construction of smart grids } \\
\text { in Australia }\end{array}$ & $\begin{array}{l}\text { A project to build distributed energy generation } \\
\text { installations that are connected to a smart grid for } \\
\text { energy redistribution. Solar panels and batteries } \\
\text { rolled out to } 50,000 \text { homes will be pulled } \\
\text { together into a single virtual power plant. Project } \\
\text { jointly implemented by an investment fund, the } \\
\text { government and Tesla. }\end{array}$ & $\begin{array}{l}\text { Energy } \\
\text { company } \\
\text { (Tesla) and } \\
\text { investment } \\
\text { fund and } \\
\text { government }\end{array}$ \\
\hline
\end{tabular}

contracts at the heart of second-generation blockchains like Ethereum to automate peer-topeer energy transactions.

Amid falling oil prices, Royal Dutch Shell started to invest in alternative energy companies. Its board of directors made a strategic decision to invest 1 billion dollars per year in renewables, and technologies of smart construction and energy management. One of its pilot projects is Inspire Energy Holdings that offers wind and solar energy at a flat subscription price. Inspire also provides smart home and energy management services via a mobile app.

Finally, there is Nest, a startup backed by telecommunications giant Google. Nest positions itself as a provider of smart services for households - from thermostats and smart energy meters to home security systems to security cameras and fire alarm systems. What makes Nest's business model peculiar is that all the devices it has ever sold are bundled into a single network using machine learning. At the moment, Nest is a service aggregator that manages over 50,000 thermostats in California and builds its economy on the network effect: the more households are connected to the platform, the more lucrative the company is. 
It is mainly developed countries that can boast of successes in technology entrepreneurship in the energy sector. By contrast, developing countries often have serious issues with institutionalizing industry-specific innovations because the structure of the energy market, its flexibility and non-discriminatory access to the market infrastructure constitute the key factors that shape a comfortable environment for innovation.

Having analyzed the peculiarities of energy markets in developed and developing countries, the authors have identified the main barriers that act as constraints technology entrepreneurship development.

A rigid legal framework that leaves companies limited or no room for independent decision making. All too often companies even have to coordinate their investment policy with the authorities, which minimizes their capacity for responding promptly to changing market requirements and for developing new technologies.

Market inertia and weak competition. Any energy market is an artificial construct that consists of naturally monopolistic companies (electric power transmission, operations control) and competitive ones (generation, sales, repair and maintenance, engineering, nonecore activities) as well as open wholesale and retail markets for electric power. The paradox is that market participants that directly interact with consumers (for example, power supply companies) find themselves at the very end of the value chain and de facto have no freedom of strategic maneuver.

Closing the gap between the current expectations of consumers and what energy companies have to offer would only be possible if the vertical hierarchy became weaker and service "in-fill layers" between centralized and distributed generation, the distribution and sales sectors. This would have a possible effect on the diffusion of innovations and boost competition in the market [26], [27].

Conservatism of market participants. The corporate culture of many energy companies often features a specific mode of behavior that does not welcome fast change. As a result, energy companies passively react to changes in the external environment and managers tend to make decisions reactively. New technologies that are perceived by the market as breakthrough ones are introduced slowly and sporadically. The search for innovations is not systemic and is not part of the company's strategy.

It is appropriate to quote energy systems expert Lee Bryant as saying in his blog that "the irony of companies that talk about smart grids, distributed networks, resilient supply and smart IoT devices, is that they operate internally using email, PowerPoint and endless meetings and conference calls. To succeed in connected markets with connected products, you need to be a connected company" [28]. The expert thus stresses that the success of energy companies depends on their readiness to employ technology and, consequently, on the availability of the organizational paradigm, flexible organizational systems and culture that encourage the process of innovation, rather than on their awareness of the technological context.

The above arguments are additionally backed by the findings of a survey that the authors conducted to ask experts at regional energy companies about their attitude to technology entrepreneurship. According to the survey, $56 \%$ of the interviewees do not implement technology entrepreneurship project, but admit it is today's big trend. An overwhelming majority of the respondents said that in most cases the only way to encourage the process of innovation is by declaring support for ideas and concepts proposed by employees rather than through systemic search for innovations (Fig. 2,3). Among the most promising trends in technology innovation, staff members of energy companies name advances in core production technologies, information systems, new services for consumers, engineering and repair services (Fig. 4). 


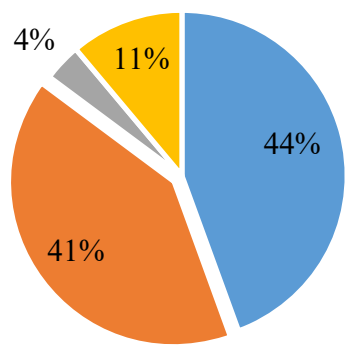

What does your company management think of technology entrepreneurship?

- They are positive about it, it's a growth point for energy business

- They are positive about it, but there is no need to develop it

- They are negative about it, it is expensive and can harm the energy company's stable performance

- I am not sure what this is about

Figure 2: Attitude of leaders of energy companies to technology entrepreneurship.

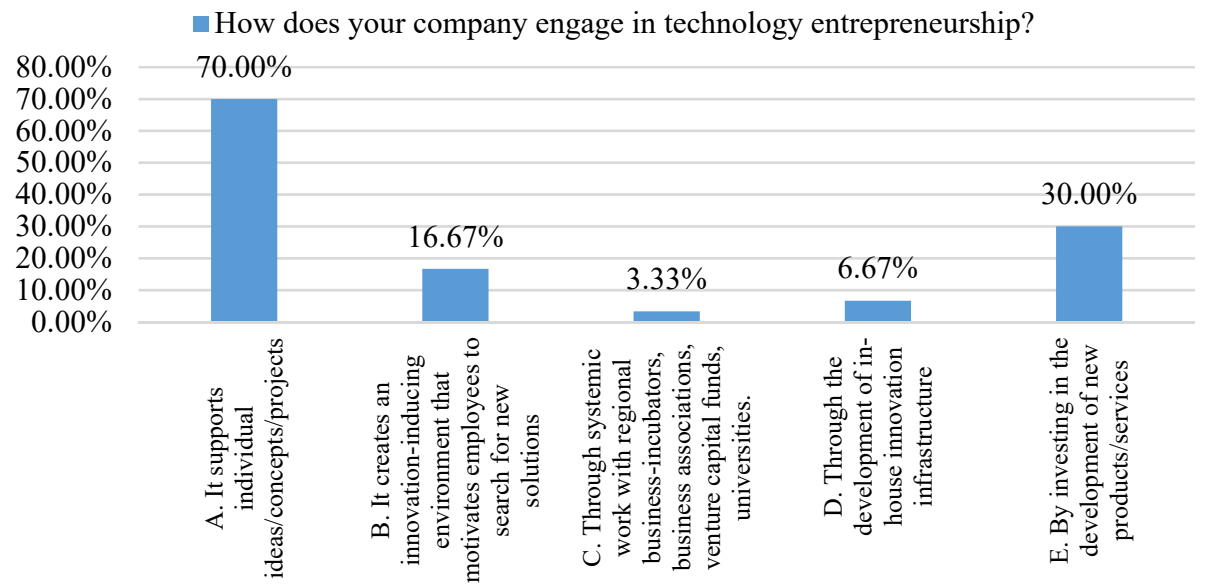

Figure 3: Ways of implementing technology entrepreneurship projects.

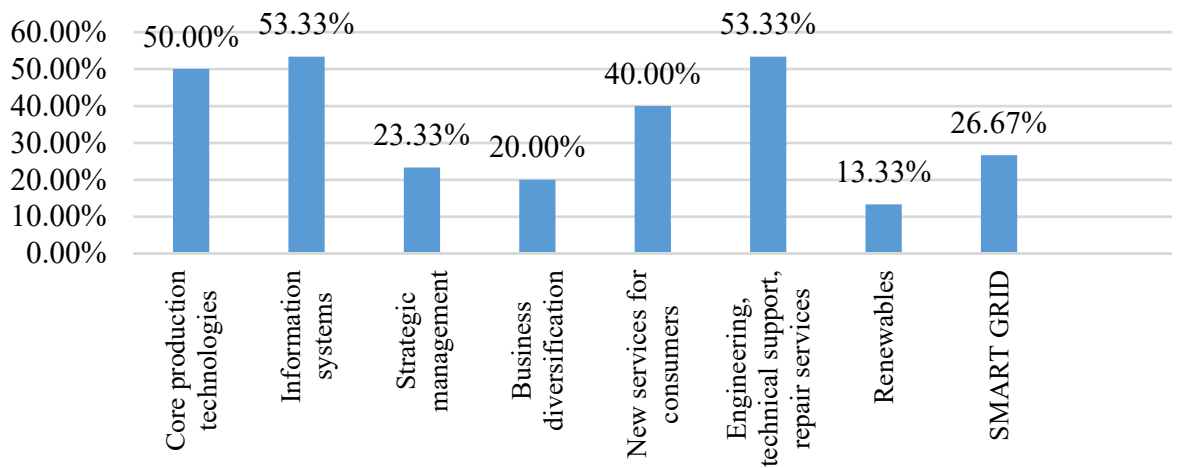

Figure 4: Promising trends in technology entrepreneurship. 


\section{MODELS OF TECHNOLOGY ENTREPRENEURSHIP IN THE ENERGY SECTOR}

Having conducted an analysis of the meaningful traits of technology entrepreneurship, actual cases and expert opinions, the authors were able to identify typical models that demonstrate mechanisms of introducing breakthrough innovative technologies, their application areas and capabilities. Table 3 is a generalized summary of the models.

Table 3: Models of technology entrepreneurship in the energy sector.

\begin{tabular}{|c|c|c|c|}
\hline Model & Description & Pros & Cons \\
\hline $\begin{array}{l}\text { Government } \\
\text { subsidies for } \\
\text { projects in major } \\
\text { energy companies }\end{array}$ & \begin{tabular}{|l|} 
Major \\
infrastructure \\
projects are \\
implemented \\
with support \\
from \\
government
\end{tabular} & $\begin{array}{l}\text { - Major projects can be implemented } \\
\text { that the company would not be able } \\
\text { to undertake on its own } \\
\text { - Some risks are covered; the } \\
\text { government acts as a "lifesaver" } \\
\text { - Access to all available infrastructure } \\
\text { that makes it easier to implement the } \\
\text { project }\end{array}$ & $\begin{array}{l}\text { - Red tape in decision } \\
\text { making affects project } \\
\text { deadlines } \\
\text { - Increased control on the } \\
\text { part of government }\end{array}$ \\
\hline \begin{tabular}{|l|} 
Energy \\
company's \\
investment in in- \\
house $R \& D$
\end{tabular} & $\begin{array}{l}\text { Intellectual and } \\
\text { financial } \\
\text { resources are } \\
\text { mobilized } \\
\text { within the } \\
\text { company and } \\
\text { used as the } \\
\text { basis for } \\
\text { creation of } \\
\text { innovations }\end{array}$ & $\begin{array}{l}\text { Technologies can be tailored to } \\
\text { specific tasks of the energy company } \\
\text { - Absence of intermediaries or other } \\
\text { parties that have an influence on the } \\
\text { process and demand performance } \\
\text { results } \\
\text { - Proprietary information can be kept } \\
\text { secret } \\
\text { - Development of corporate R\&D and } \\
\text { positive changes in the } \\
\text { organizational culture of the business }\end{array}$ & $\begin{array}{l}\text { - Higher risks as the } \\
\text { company fully funds } \\
\text { projects } \\
\text { - As a result, big capital- } \\
\text { intensive projects } \\
\text { become unfeasible } \\
\text { - A project is at risk of not } \\
\text { getting a comprehensive } \\
\text { implementation because } \\
\text { the company may not } \\
\text { have the necessary } \\
\text { expertise of resources }\end{array}$ \\
\hline $\begin{array}{l}\text { Commercializatio } \\
\text { n of university } \\
\text { R\&D by energy } \\
\text { companies }\end{array}$ & \begin{tabular}{|l|} 
University \\
R\&D products \\
are \\
transformed \\
into marketable \\
products
\end{tabular} & $\begin{array}{l}\text { - An opportunity to convert } \\
\text { technologies that business may not } \\
\text { have considered profitable or } \\
\text { promising into innovations } \\
\text { - University has an abundance of } \\
\text { intellectual resources that could be } \\
\text { utilized in current and subsequent } \\
\text { projects } \\
\text { - An opportunity to perfect mechanisms } \\
\text { of knowledge and technology transfer, } \\
\text { cooperation and networking } \\
\text { - Access to new staff and } \\
\text { competencies }\end{array}$ & $\begin{array}{l}\text { - Lack of managerial } \\
\text { experience requires the } \\
\text { presence of consultants } \\
\text { on the team } \\
\text { - Few companies have the } \\
\text { potential to be } \\
\text { commercially successful }\end{array}$ \\
\hline \begin{tabular}{|l} 
Launch of \\
startups as a \\
standalone or \\
daughter business
\end{tabular} & \begin{tabular}{|l|} 
Investment is \\
attracted for \\
startup launch
\end{tabular} & $\begin{array}{l}\text { - Absence of red tape and complete } \\
\text { freedom of creation } \\
\text { - Broad opportunities for testing } \\
\text { technologies/products/services being } \\
\text { created }\end{array}$ & $\begin{array}{l}\text { - Very high risk of project } \\
\text { failure or the failure to } \\
\text { find a working business } \\
\text { model } \\
\text { - Involvement of } \\
\text { professional consultants } \\
\text { is required to help the } \\
\text { startup survive through } \\
\text { growth stages }\end{array}$ \\
\hline
\end{tabular}


Government subsidies for projects in major energy companies. The majority of projects in the energy sector require huge investment. In most cases, it is the government that acts as the guarantor as it is ready to invest overhaul projects in critical infrastructure by taking on the biggest share of obligations to absorb financial and organizational risks.

Such a model of implementing national and regional energy projects is typical of strategic initiatives and can be used for smart city development projects and smart energy systems, distributed generation clusters, pilot generation installations employing emerging technologies. From the point of view of technology entrepreneurship, energy companies can be interested in the model because it opens up opportunities for the development of innovative industrial infrastructure but can hardly help it build its own entrepreneurial competences.

An energy company's investment in in-house $R \& D$. Mobilizing intellectual and financial resources within the energy company and creating innovations on the basis of emerging growth points is another popular model. The majority of big corporations that hold stable positions in national and global markets opt for this model of entrepreneurial behavior. To execute the model, a standalone corporate unit can be set up that takes responsibility for the process of innovation and performs context analysis, conducts R\&D activities and product testing. If the tests prove successful, the energy company may turn this activity into a separate business. The model is typical of projects that are aimed at business process optimization or the improvement of technologies in use.

Commercialization of university $R \& D$ with the help of external financing. The model is essentially about building close cooperation with universities for conducting research, acquiring new knowledge and unique R\&D achievements. The model could be utilized by energy companies in local projects of technology modernization but are most frequently employed when creating breakthrough and fundamentally new technologies. One vivid example is numerous partnerships of leading players in the nuclear market to design Gen IV nuclear reactors.

Launch of startups. The model is picked by both enthusiasts who are prepared to seek financing for their ideas, and by companies whose core business lies outside the energy sector, but who want to diversity into the energy market. The range of products that can be developed within the framework of the model is immensely broad and can include information applications for consumers, new equipment, systems of energy process monitoring, components for smart energy systems. The startup model is a service one from the energy market perspective and has a huge potential for creating specialized platforms of technology entrepreneurship.

Relations between the models are depicted in Fig. 5. This conceptual scheme integrates the main connections and functions of the process participants, directions of their resource and information interactions. The scheme could be used for the development of technology entrepreneurship infrastructure.

\section{CONCLUSION}

The presented models can be employed by heads of energy companies as an effective tool for ramping up the process innovation, creating long-lasting competitive advantages, building customer relationships, and supporting complex projects of technology modernization. Given the complex attitudes to technology entrepreneurship in the energy sector, one needs to define baseline conditions the absence of which makes it inexpedient to embrace technology entrepreneurship. 


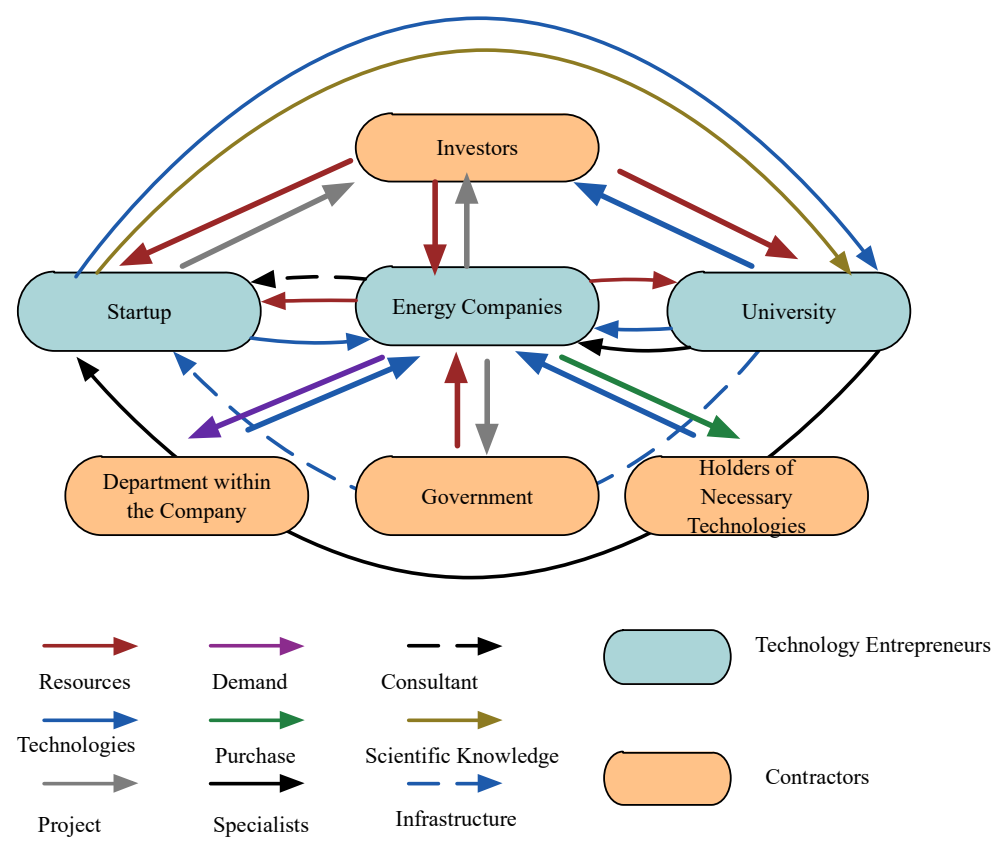

Figure 5: Integrated scheme of technology entrepreneurship models in energy sector.

Technology entrepreneurship is good for implementing breakthrough ideas whether it comes to technology, products, services or management systems. Otherwise one may not be able to recoup the costs and the risks will make not worth the effort. The energy company must have a clear idea of its position and resources in the chain of breakthrough innovations that correspond to trends in the regional, national, or global energy policies - depending on the size of the energy business.

Technology entrepreneurship is difficult to do without $R \& D$ and close cooperation with science. That's why universities and energy companies that focus on innovation establish special closely interlocking structures for knowledge transfer that are designed to monitor the latest achievements in science and technology and exchange best practices.

Technology entrepreneurship cannot be done without building teams that continuously search for new ideas, methods of their implementation and create a flow of innovation a kind of bloodstream in the energy company. It becomes vital to create appropriate organizational culture without which not a single stage of technology entrepreneurship can be executed.

These ideas are the subject of further research and require additional elaboration. The authors' own experience [29], [30] of forming breakthrough teams in energy companies and developing smart partnerships of energy business, science and education has been highly successful and provides a convincing proof of the practical relevance of technology entrepreneurship as an instrument of responding to industry challenges.

\section{ACKNOWLEDGEMENT}

The work was supported by Act 211 of the Government of the Russian Federation, contract № 02.A03.21.0006. 


\section{REFERENCES}

[1] Christensen, C.M., The Innovator's Dilemma: When New Technologies Cause Great Firms to Fail, Harvard Business School Press: Boston, 1997.

[2] Linden, A. \& Fenn, J., Understanding Gartner's Hype Cycles, Strategic Analysis Report. Www.bus.umich.edu/KresgePublic/Journals/Gartner/research/115200/ 115274/115274.pdf. Accessed on: 30 Jul. 2018.

[3] Dedehayir, O. \& Steinert, M., The hype cycle model: A review and future directions. Technological Forecasting and Social Change, 108(C), pp. 28-41, 2018. DOI: 10.1016/j.techfore.2016.04.005.

[4] Abdullah, S., Musa, C.I. \& Azis, M., The effect of organizational culture on entrepreneurship characteristics and competitive advantage of small and medium catering enterprises in Makassar. International Review of Management and Marketing, 7(2), pp. 409-414, 2017.

[5] Muñoz, R.M., de Pablo, J.D.S., Peña, I. \& Salinero, Y., The effects of technology entrepreneurship on customers and society: A case study of a Spanish pharmaceutical distribution company. Frontiers in Psychology, 7, pp. 1-13, 2016.

DOI: 10.3389/fpsyg.2016.00978.

[6] International Energy Agency. World Energy Investment 2017. www.iea.org/ publications/wei2017/. Accessed on: 30 Jul. 2018.

[7] Mas, M., Fernández de Guevara, J., Robledo, J.C. \& López-Cobo, M., The 2017 PREDICT Key Facts Report. An Analysis of ICT R\&D in the EU and Beyond, 2017. http://publications.jrc.ec.europa.eu/repository/bitstream/JRC106658/kjna28594enn.p df. Accessed on: 30 Jul. 2018.

[8] Cooper, Arnold C. \& Komives, John L. (eds), Technical Entrepreneurship: A Symposium. Center for Venture Management, Milwaukee, WI, 1972.

[9] Florida, R. \& Kenney, M., Venture capital and high technology entrepreneurship. Journal of Business Venturing, 3(4), pp. 301-319, 1988. DOI: 10.1016/08839026(88)90011-0.

[10] Bahrami, H. \& Evans, S., Flexible re-cycling and high-technology entrepreneurship. California Management Review, 37(3), pp. 62-89, 1995. DOI: 10.2307/41165799.

[11] Kenney, M. \& von Burg, U., Technology, entrepreneurship and path dependence: Industrial clustering in Silicon Valley and Route 128. Industrial and Corporate Change, 8(1), pp. 67-103, 1999. DOI: 10.1093/icc/8.1.67.

[12] Shane, S. \& Venkataraman, S., Guest editor's introduction to the special issue on technology entrepreneurship. Research Policy, 32(2), pp. 181-184, 2004.

DOI: $10.1016 / \mathrm{s} 0048-7333(02) 00104-x$.

[13] Bailetti, T., Technology Entrepreneurship: Overview, Definition, and Distinctive Aspects, Technology Innovation Management Review. https://timreview.ca/ article/520. Accessed on: 30 Jul. 2018.

[14] Gabriel, C.-A. \& Kirkwood, J., Business models for model businesses: Lessons from renewable energy entrepreneurs in developing countries. Energy Policy, 95, pp. 336346, 2016. DOI: 10.1016/j.enpol.2016.05.006.

[15] Morris, D., Siemens to Invest in Blockchain-Based Smart Grid Builder LO3, Fortune. http://fortune.com/2017/12/24/siemens-blockchain-lo3. Accessed on: 30 Jul. 2018.

[16] South China Morning Post, "Forget the Facebook leak": China is mining data directly from workers' brains on an industrial scale. www.scmp.com/news/china/society/ article/2143899/forget-facebook-leak-china-mining-data-directly-workers-brains. Accessed on: 30 Jul. 2018. 
[17] Nikolaev, M.V., Ovsyannikov, A.Yu. \& Marchinsky, I.Yu., Experience of using smart networks in Russia. Technology Smartgrid. Young Scientist, 28(2), pp. 63-68, 2016, https://moluch.ru/archive/132/37010. Accessed on: 30 Jul. 2018.

[18] Woyke, E., General Electric Builds an AI Workforce, MIT Technology Review, www.technologyreview.com/s/607962/general-electric-builds-an-ai-workforce. Accessed on: 30 Jul. 2018.

[19] Carnegie Melon University, Press Release: Carnegie Mellon Researchers Develop Dashboard to Help Reduce Energy Use in Office Buildings. www.cmu.edu/news/ stories/archives/2014/april/april7_workplacedashboard.html. Accessed on: $30 \mathrm{Jul}$. 2018.

[20] Allan, R., Researchers look to materials to Improve Micro-Grid Renewable Energy Storage. www.electronicdesign.com/power/researchers-look-materials-improvemicro-grid-renewable-energy-storage. Accessed on: 30 Jul. 2018.

[21] Eckhouse, B. \& Gilblom, K., Shell's Pivot to Renewables Sharpens with California Deal, Bloomberg. www.bloomberg.com/news/articles/2018-02-14/shell-makesanother-bet-on-renewable-energy-with-inspire-deal. Accessed on: 30 Jul. 2018.

[22] Peteranderl, S., Crossrail will generate electricity using the wind created by trains, Wired. www.wired.co.uk/article/city-wind-farms-energy-crossrail-london-renewableenergy. Accessed on: 30 Jul. 2018.

[23] Lambert, F., Tesla is installing Powerwalls and solar power on 50,000 homes to create biggest virtual power plant in the world, Electrek. https://electrek.co/2018/02/04/teslapowerwall-solar-virtual-power-plant. Accessed on: 30 Jul. 2018.

[24] Peters, A., These Oil Industry Workers Now Teach Their Colleagues How To Install Solar, Fast Company. www.fastcompany.com/40506161/these-former-oil-industryworkers-now-teach-their-old-colleagues-how-to-install-solar?utm_source $=$ feedly \& utm medium=webfeeds. Accessed on: 30 Jul. 2018.

[25] Buchmann, M., Digital Platforms in the Energy Sector: Definition and First Applications www.theenergycollective.com/enerquire/2410260/digital-platformsenergy-sector-definition-first-applications. Accessed on: 30 Jul. 2018.

[26] Pelzer, A., Lombardi, P., Arendarski, B. \& Komarnicki, P., An innovative energy management system for the integration of volatile energy into industrial processes. International Journal of Energy Production and Management, 1(4), pp. 339-348, 2016. DOI: 10.2495/eq-v1-n4-339-348.

[27] Weiller, C.M. \& Pollitt, M.G., Platform markets and energy services. Working Paper, 2013. Www.eprg.group.cam.ac.uk/wp-content/uploads/2013/12/1334-PDF.pdf. Accessed on: 30 Jul. 2018.

[28] Bryant, L., Can utility companies make the transition to energy platforms? https://postshift.com/can-utility-companies-make-the-transition-to-energy-platforms/. Accessed on: 30 Jul. 2018.

[29] Gitelman, L.D. \& Kozhevnikov, M.V., A paradigm of managerial education for a technological breakthrough in the economy [in Russian]. Economy of Region, 14(2), pp. 433-449, 2018. DOI: 10.17059/2018-2-8.

[30] Gitelman, L.D., Gavrilova, T.B., Kozhevnikov, M.V. \& Starikov, E.M., Ensuring resilience and agility of complex organizational-technical systems. International Journal of Design \& Nature and Ecodynamics, 13(2), pp. 208-220, 2018. DOI: 10.2495/DNE-V13-N2-208-220. 